\title{
A national project on three-dimensional geology of Italy: 3D model of Monti della Cesana from Sheet 280 - Fossombrone
}

1. Centro di Oceanografia e Geologia Ambientale, Università di Urbino, Campus Scientifico, 61029 Urbino, Italy.

2. Midland Valley Exploration Ltd., 14 Park Circus, Glasgow, G3 6AX Scotland, United Kingdom.

3. Servizio Geologico Nazionale, Dipartimento per i Servizi Tecnici Nazionali, Via Curtatone 3, 00185 Roma, Italy.

The National Project for the creation of a three-dimensional geological model of Italy has been made possible by the collaboration of the Centre of Oceanography and Environmental Geology of Urbino University, the Geological Survey of Italy and Midland Valley Exploration.

The purpose of this work is to show the methodology for building the $3 D$ geological model of Italy as well as outlining types of analysis, which may be carried out on such a model. The geological model will be based on map Sheet 280 - Fossombrone, on the scale of 1:50,000, from the new national geological mapping program.

The study sector is limited to the Monti della Cesana open anticline where Mesozoic to Paleogene passive margin carbonates and Neogene terrigenous foreland basin sediments outcrop.

The data used included a 3D digital elevation model (DEM) from the topography, field data as well as a number of cross-sections. On completion of the 3D model, a geometric analysis of the drainage system and potential water/sediment flow pathways was carried out on the topography.

The next stage of the project will be to integrate the geophysical data (well logs, seismic reflection profiles and gravimetric data) with the current model in order to create a more complete $3 D$ geological model extended down to the basement.

\section{Introduction}

One of the major challenges faced by the geologist is to visualise and predict the geometry of geological structures at depth. These challenges are even greater when working in the third dimension (Slatt et al., 1996). Three dimensional and four dimensional (3D and 4D) modelling of geological structures is currently used within the oil and mining industry as well as by some geological survey projects (i.e. B.R.G.M. in France).
Current advances in the production of the Geological Map of Italy, combined with geological and geophysical data supplied by the academic and industrial worlds have enabled the commencement of a national project for the production of a three-dimensional geological model of Italy. Co-operation among the Centre for Oceanography and Environmental Geology (C.O.Ge.A) of the University of Urbino, the Italian Geological Survey (S.G.N. - Rome) and Midland Valley Exploration (Glasgow - U.K.) have made it possible to carry out a pilot study to define a methodology for constructing a 3D structural geological model of a selected area of Italy.

The main aim of the national project is to establish possible uses of 3D structural modelling in understanding and improving technical and geological risks. These risks are currently qualified using geological models based only on field survey data.

An improved and well-founded geological model has implications on both commercial issues (i.e. Planning and validation of scale models for waste disposal) and geological issues (i.e. Increase awareness of regional tectonics leading to improved regional mod-

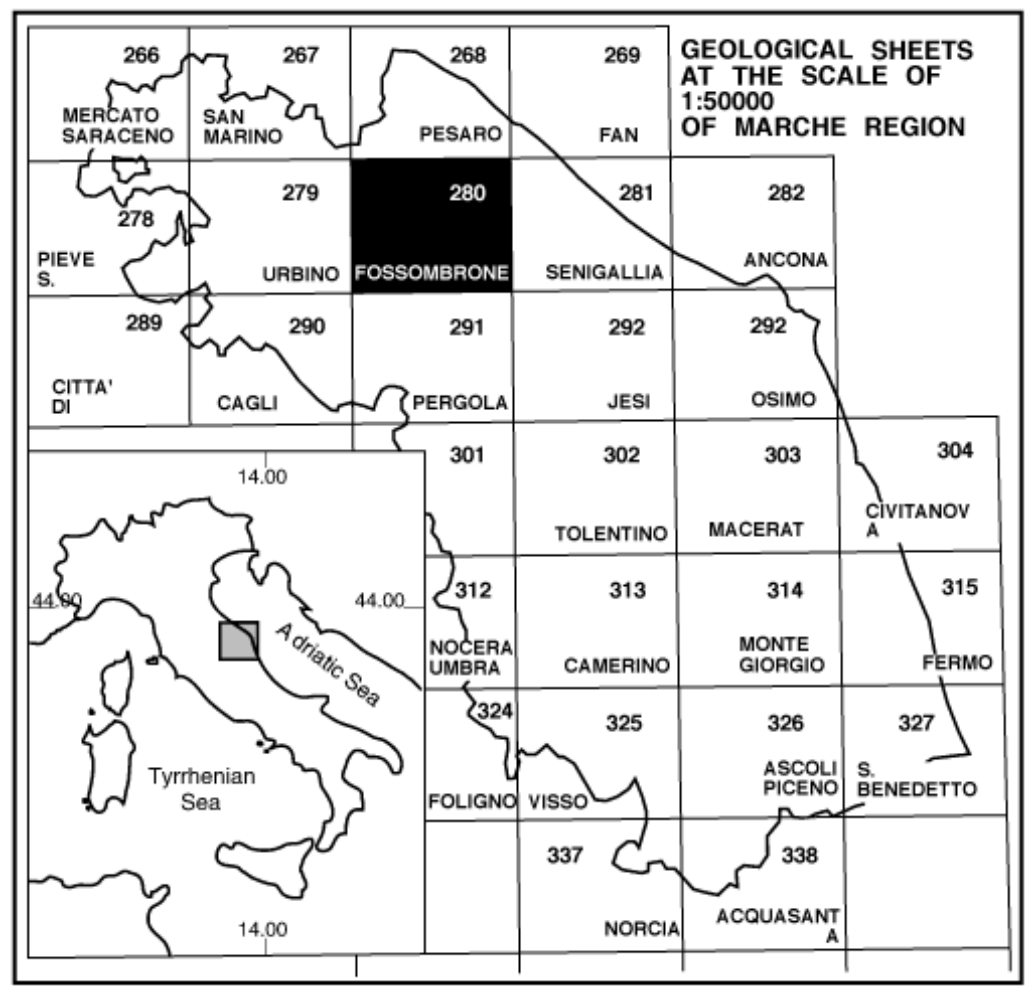

Figure 1 Location map of the Sheet 280 - Fossombrone. 


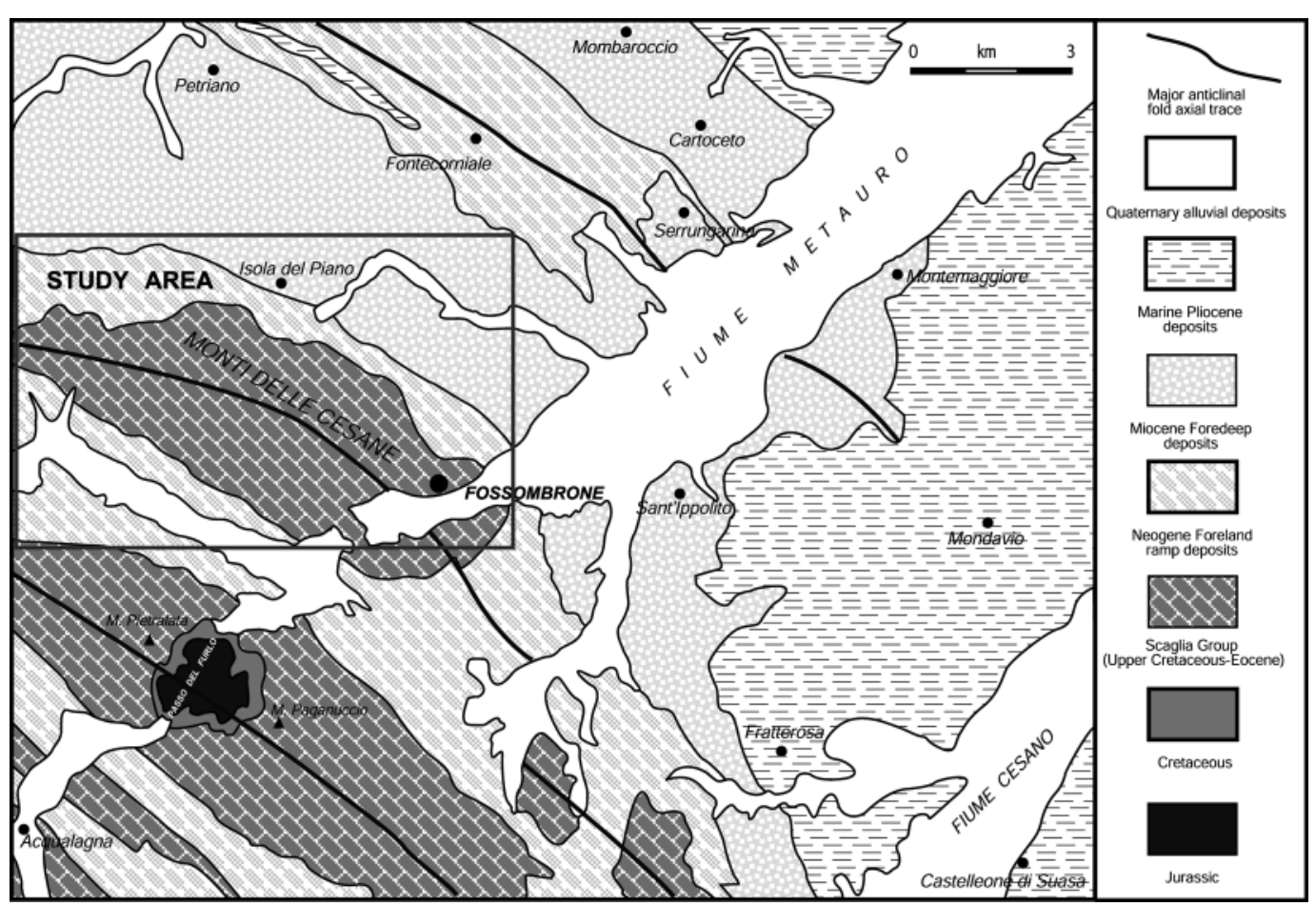

Figure 2 Geological sketch of the Sheet 280 - Fossombrone with location of the study area.

and understanding complex structural problems.

\section{Geological setting}

The stratigraphy of Sheet 280Fossombrone can be summarized as follows (Figure 2). A Mesozoic-Paleogene carbonate succession typical of a passive margin is detached from the Permo-Triassic basement by the middle-upper Triassic anhydrites and covered by a predominantly terrigenous succession of Neogene foreland basin sediments up to the Pliocene marine deposits (Carloni et al., 1971). Quaternary continental deposits include fluvial terraced sediments and alluvial fans, periglacial stratified debris and landslides. The overall structure can be described as a number of anticline-syncline pairs detached from the basement by buckling and cut by thrusts and backthrusts related to the orogenic

els). Moreover, by using an integrated approach with a 3D tool, it is intended to make geological information more accessible to a wider audience of non-geological specialists and decision-makers who can use the geological information to better predict, plan and then manage the results and implications of geological risk assessment projects.

The Fossombrone map, which was surveyed by the S.G.N for the new Geological Map of Italy, has been selected as the study area (Figure 1,2). The in-depth knowledge of the regional and local geology combined with the availability of subsurface (well and seismic) data makes the area ideal for defining a suitable methodology for creating a 3D geological model for other areas of Italy. The study area is also of interest due to its location within a high risk zone for major geological hazards such as earthquakes, floodings and landslides (AA.VV., 1994; Regione Marche, 1991). On top of this, there is a relatively high population density within the region.

\section{Aims and methods}

The primary purpose of the 3D modelling is to enhance the current geological interpretations from the current Geological Map of Italy, in order to understand and/or reduce the technical and commercial risks associated with poorly constrained data.

A better geological model has, for instance, profound implications on planning strategy for waste disposal sites or in the management of the hydrological system.

The methodology applied, within this project, to create the 3D model within the study area will be used to help with the definition of national guidelines for building 3D geological models on various scales, using the new 1:50,000 National Geological Maps as the major data source.

The methodology consists of combining a variety of data types within 3D structural modelling and visualisation tools such as 3DMove (De Donatis, 2001). The available geological and geophysical data are used to build a 3D structural model, the model is then combined with the Digital Elevation Model (DEM) data for the topographic surface to create a 3D structural model of the study area within its present day geographic setting. Results from analogue modelling experiments, together with satellite imagery, are integrated in the $3 \mathrm{D}$ model, in order to enhance the ability of interpreting events which have produced the Apennines mountain belt (Lavecchia, 1981; Menichetti et al., 1991; De Donatis at al., 1995; Barchi et al., 1996).

We focus our work on the sector of the Monti della Cesana antiformal high, NW of the town of Fossombrone, where the Paleocene to Oligocene limestones of the Scaglia Group crop out. The lithostratigraphic succession consists of the upper part of the Scaglia Rossa Fm. (from Paleocene to lower Eocene in age), the Eocene Scaglia Variegata Fm. and the upper Eocene-Oligocene Scaglia Cinerea Fm. The early Miocene age is represented by the limestones and volcanoclastics layers of the Bisciaro Fm., which are conformably overlain by the middle Miocene marls of the foreland ramp environment (Schlier Fm.). The first foredeep deposits of this sector are upper Miocene terrigenous deposits of the Marnoso-Arenacea Fm. The middle Messinian salinity crisis is recorded by evaporitic limestones and gypsum as well as the bituminous pelitic sediments (Gessoso Solfifera Fm.). Overlying the latter, the upper Messinian Colombacci Fm. of transitional environment are unconformably covered by deeper marine Pliocene deposits.

Landslides are present on both flanks of Monti della Cesana, whilst alluvial and debris deposits are present in the topographic depression.

The tectonic structure can be described as a large open anticline within the hangingwall of a blind thrust which has a relatively large fault displacement. The thrust detaches in the Triassic Anhydrites and has not penetrated the upper Miocene terrigenous and evaporitic deposits (Mazzoli et al., 2001).

\section{The 3D model of Monti Della Cesana}

The topography of the area and the geological boundaries were imported into the 3DMove software from the Geographic Information System (GIS) of the S.G.N., and a triangulated mesh DEM was built honouring the topographic contour data. The digital image of the geological map has been integrated onto the DEM, by superimposing the image onto the $3 \mathrm{D}$ topography. The result is a full $3 \mathrm{D}$ representation of the outcropping geology (figure $3 a$ ). 


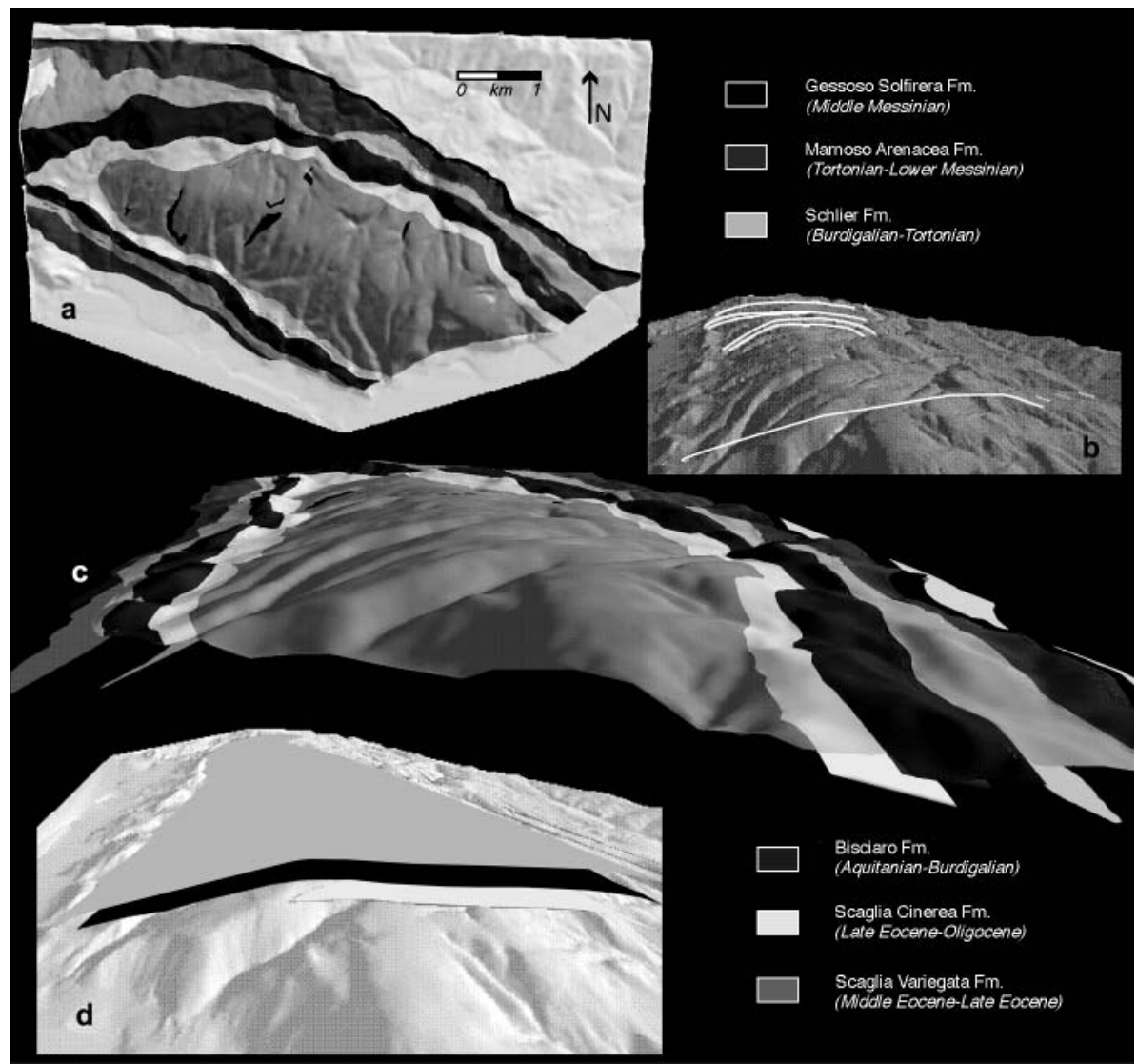

Figure 3 Building the 3D geological model. (a) Map view of the model showing the geology imported on to the digital elevation model; (b) DEM with the referenced geological te cross sections; (c) the 3D geology viewed from ESE; (d) the stratigraphy "missing" for erosion.

In order to start the construction of the subsurface geology, four georeferenced geological cross-sections made from the field survey were inserted into the previously constructed 3D model of the outcropping geological formations (Figure 3b). These cross-sections, together with the surface geological boundaries, were used as the starting point to build the structural models at depth. The technique involves joining together lines representing the same stratigraphic horizons or faults to form continuous 3D surfaces (Figure 3c).

The first 3D model shows the open and gentle anticlinal structure of the Monti della Cesana with its periclinal closure towards the NW (Figure 3a, c). This simple 3D model highlights unresolved problems and unconstrained regions within the 2D maps and sections from the study area. In fact the mapping of certain lithological boundaries was constrained using the 3D model.

On completion of the 3D model, further analysis may be carried out to quantify the rates and timing of stratigraphic loading and erosion (Figure 3d), using the 3D geological model to constrain the missing stratigraphic volume as well as carrying out palaeogeographic modelling.

\section{Integration of fluid and sediment modeling techniques into the 3D model}

Fluid and sediment modeling techniques and concepts were applied to the 3D triangulated DEM surface in order to provide an insight into the hydrological (surface water) and depositional system of the study area (Figure 4). The surface has been analysed for fluid/sediment migration pathways and associated drainage areas

Potential sediment migration pathways are defined by down-dip geometric fluid or material flow lines that are initiated from a source point and follow the steepest geometric route. The flow lines terminate at local depocentres. Drainage areas are defined and bounded by watersheds. Depocenters in the drainage areas are identified as points of lowest depth value within each local drainage area.

The potential sediment migration pathways are illustrated in Figure 4a. The figure illustrates a map view of the study area, gray scale mapped for elevation (higher elevation in dark gray), with the present day sediment flow pathways visualised in white. A perspective view of the surface is shown in Figure $4 \mathrm{~b}$. Please note how the pathway analysis successfully picks out the present day drainage pat-

Figure $4 \mathrm{c}$ is a map view of the topographic surface with the drainage areas, while Figure $4 \mathrm{~d}$ is a perspective view of the topographic surface with both the drainage areas analysis and the potential sediment pathway

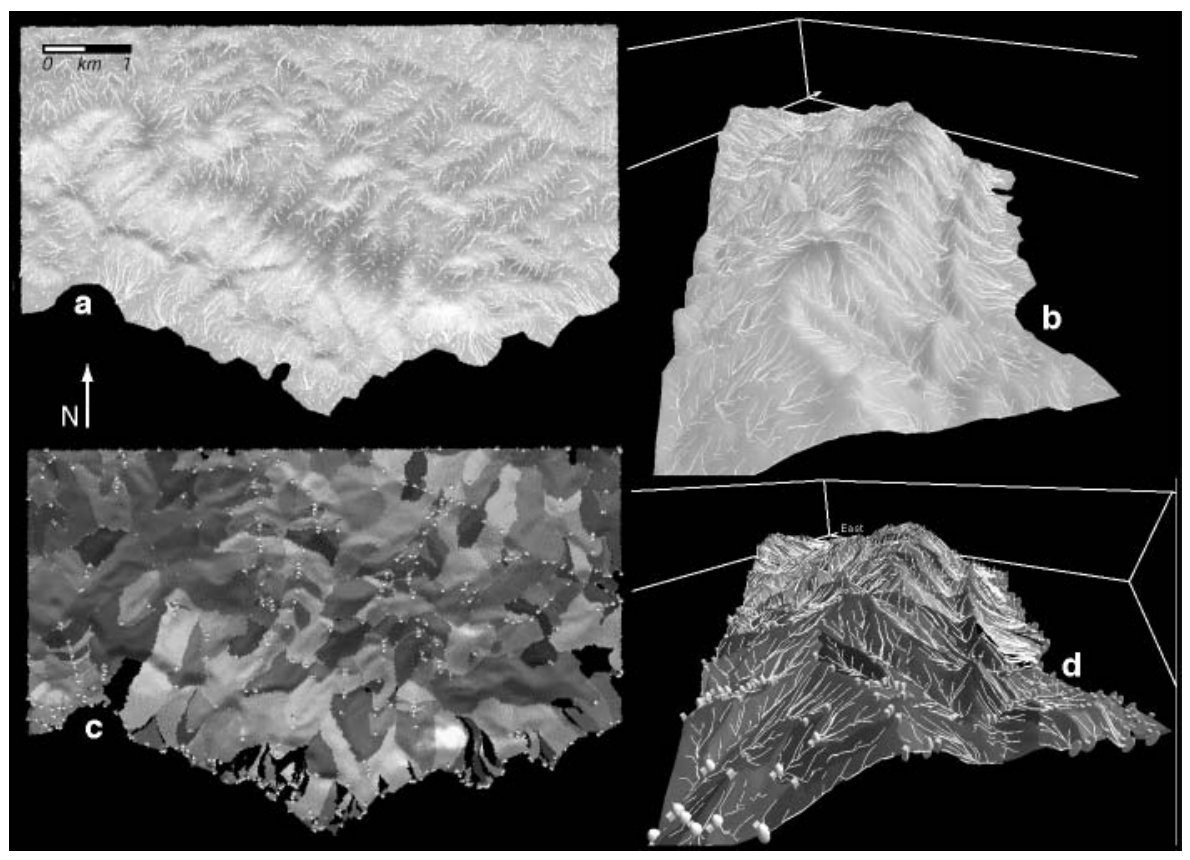

Figure 4 Geomorphologic analysis. 9a) Map view of the DEM with "flow-pathway" systems; (b) Viewed from NW; (c) Map view of the drainage system with catchment areas; (d) Viewed from $N W$. 
analysis. Please note the position of the inter-mountain basins and depocentres.

Cubes in Figure 4c represent potential "Nick Points", (identified as points along a drainage area boundary which are the lowest depth value point shared with a neighboring drainage area), while white spheres represent depocenter points.

Once a nick point becomes active (i.e. the accommodation space within the drainage cell has been infilled by sediment) it is assumed that the fluid/sediment is now by-passing the associated drainage area into a geometrically lower drainage area therefore modeling the most likely geometric route for sediment dispersion. This enables, for example, the ability to locate the most likely geometric point at which the position of potential incised valleys and their associated alluvial fan deposits may be developed.

The sediment flow pathway and drainage area analysis produces a number of statistical outputs, such as the surface area of each individual drainage area, the potential sediment infill volume/ accommodation space (maximum amount of sediment able to infill a single basin), and the position of the depocenters and nick points and their activity. Both the 3D visualization and statistical output of the fluid flow and drainage area analysis are useful from the geological modeling perspective. The results from this type of analysis may also have a positive on hazard risk assessment and in planning and managing the viability of infrastructures such as building dams or waste disposal sites. Drainage area analysis for instance may be used to quantify the upstream catchments area, which in turn may be used to assess reservoir filling potential.

\section{First conclusions and future expected results}

Building of a 3D model of the Monti della Cesana area is the first step towards achieving the creation of a valid $3 \mathrm{D}$ geological model of the Fossombrone area. This work was carried out using only a limited data source of field data such as maps and cross sections. Nevertheless the production of a 3D geological model, by the three dimensional correlation of horizons, has enabled the direct visualisation of the structure in true 3D. As a result, the geological uncertainties of the field data, highlighted in the 3D model, were investigated and improved upon at various scales.

The integration of fluid and sediment modeling techniques into the 3D geological model has provided a useful insight into the hydrological (surface water modelling) and sediment dispersal analysis of the studied area, identifying sediment/fluid migration pathways, drainage areas and watersheds. The outputs of the sediment and fluid modeling are important for an integrated geological analysis, but may also be of benefit in hazard risk assessment and water resources engineering studies.

The next stage of the project will be to integrate the well logs and geophysical data (seismic, gravimetric, etc.,) to the current 3D model, in order to built an improved structural model of the study area. More effort will be placed in understanding the kinematic mechanisms that created the Monti della Cesana structure. This will be achieved by using forward modelling and restoration techniques.

Similarly, the fluid and sediment modelling techniques will be extended to the whole area of Sheet 280 and integrated with the results of satellite image analysis. This will provide a better understanding of the present day hydrological and sedimentological models of the area.

By using a 3D tool to visualize the geological model(s) of the area, we intend to make geological information more accessible to a wider audience of non-specialist users, such as engineers and decision-makers who can use the geological information to better predict, plan and manage the impacts caused by the development of new infrastructure. Moreover, with this project, we intend to provide a description of national guidelines for building 3D geological models on various scales, using the new National Geological Maps on a scale of 1:50,000 as the initial data source.

\section{References}

AA.VV. ,1994, 15 Itinerari - Appennino Umbro-Marchigiano: Società Geologica Italiana, p. 301.

Barchi, M., De Feyter, A.J., Magnani, M.B., Minelli, G., Pialli, G., and Sotera, B.M.,1996, L'avampaese deformato dell'Appennino Settentrionale e il suo stile strutturale: Presentazione dei risultati del profilo sismico CROP 03: Volume dei Riassunti, 7-9 November 1996, Rome, pp. $7-$ 8.

Carloni, G. C., Colantoni, P., Cremonini, G., D'Onofrio, S., and Selli, R., 1971, Note illustrative della Carta Geologica d'Italia alla scala 1:100.000. Fogli 109-110-117, Pesaro-Senigallia-Jesi: Servizio Geologico d'Italia, . 62pp.

De Donatis, M., 2001, Three-dimensional visualisation of the Neogene structures of an external sector of the Northern Apennines, Italy: AAPG Bulletin, v. 85, no.3, pp. 419-431.

De Donatis, M., Mazzoli, S., Paltrinieri, W., and Wezel, F. C., 1995, Evoluzione tettonica dell'avanfossa appenninica marchigiano-romagnola dal Miocene superiore al Pleistocene: Studi Geologici Camerti, Vol. spec., pp. 359-371.

Lavecchia, G., 1981, Appunti per uno schema strutturale dell'Appennino Umbro-Marchigiano. 3. Lo stile deformativo: Bollettino della Societ: Geologica Italiana, v. 100, pp. 271-278.

Mazzoli, S., Lanci, L., and De Donatis, M., 2001,. Paleomagnetic rotations in thrust belts: A case-study from the Marche-Romagna area (northern Apennines, Italy): Journal of Geodynamics, v. 32, pp. 373-393.

Menichetti, M., De Feyter, A. J., and Corsi, M., 1991, CROP 03 - Il tratto Val Tiberina-Mare Adriatico. Sezione geologica e caratterizzazione tettonico-sedimentaria delle avanfosse della zona Umbro-MarchigianoRomagnola: Studi Geologici Camerti, Vol. spec., pp. 279-293.

Regione Marche, 1991, L'Ambiente Fisico delle Marche: Selca - Firenze, p.255pp. (2 maps.)

Slatt, R. M., Thomasson, M. R., Romig, P. R., Pasternack, E. S., Boulanger, A., Anderson, R. N. and Nelson, H. R., 1996, Visualisation Technology for the Oil and Gas Industry: Today and Tomorrow: AAPG Bullettin, v. 80, no.4, pp. 453-459.

Mauro De Donatis is an Associate Professor at the University of Urbino where he received a Degree in Geological Sciences in 1987. He also received a post-graduate qualification in Geological Cartography in Bologna (1988) and a M.Sc. degree in Basin Evolution and Dynamics from Royal Holloway (University of London, 1996). He has been consultant for regional and national geological cartography projects. His current research is mainly focused on thrust and strike-slip tectonics and sedimentation in foreland basin settings, integrating fieldwork and interpretation of satellite images and seismic profiles with computer-assisted analysis and modelling.

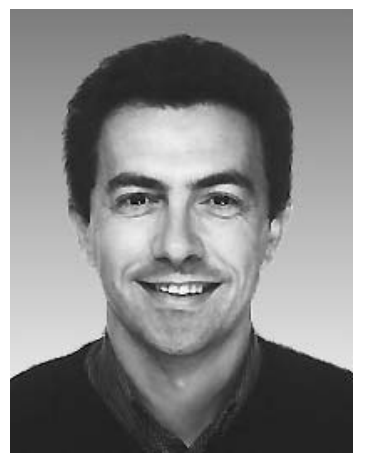

